\title{
The Prevalence of Stress Among Medical Students Studying an Integrative Curriculum During the COVID-19 Pandemic
}

\author{
Ihab Shafek Atta (iD) ${ }^{1,2}$ \\ Abdullah Almilaibary ${ }^{3}$ \\ 'Pathology Department, Faculty of \\ Medicine, Al-Azhar University, Assuit, \\ Egypt; ${ }^{2}$ Pathology Department, Faculty of \\ Medicine, Albaha University, Albaha, \\ Saudi Arabia; ${ }^{3}$ Family and Community \\ Medicine Department, Faculty of \\ Medicine, Albaha University, Albaha, \\ Al-Aqiq, Saudi Arabia
}

Purpose: Stress is a psychological shift that negatively affects student achievement. We sought to investigate the extent of stress in the medical students at our university.

Patients and Methods: A total of 337 medical students representing three program phases were represented. Stress was measured using a questionnaire divided into three main parts: 10question Kessler instruments, 10-questions specific to identifying the causes of stress, and a qualitative component to report additional information. For the Kessler questionnaire, a score of less than 20 was considered negative for stress of any level (alert) and scores of 20 24 were considered mild stress (resistance phase), 25-29 moderate stress (near exhaustion), and 30-50 severe stress (exhaustion). Descriptive studies in the form of mean, standard deviation, and confidence interval (CI) were used in addition to the chi-squared test for estimate significant differences between variables. A P-value of $<0.05$ was considered significant.

Results: The prevalence of stress was $85.5 \%$, with a slight male predominance. The prevalence of stress was seen among the male students during Phase I (88.25\%), followed by male students during Phase III (87.7\%), female students during phase II $(86.5 \%)$, male students during phase II (84.5\%), female students during phase I (83.3\%) and female students during phase III $(80.4 \%)$. Stress was uniformly high during phase I $(86.2 \%)$ followed by phase II (85.4\%) and phase III $(85.1 \%)$, and $85 \%$ of stress was obtained from the number and content of assessments.

Conclusion: There is a high level of stress throughout the curriculum. The number of assessments and the number of modules and their content are the primary sources of stress. Student mentorship, including academic, psychic, and social counseling, may help predict and manage stress and improve student performance. Detection of stress among the students is a major issue for program monitoring and development.

Keywords: academic performance, COVID-19, integrated curriculum, stress

\section{Introduction}

Medical school curricula primarily provide graduates with three main attributes: knowledge, skills/professionalism, and values. However, these attributes may be adversely affected by student distress such as anxiety, depression, burnout, and other psychological problems. ${ }^{1}$ In general, psychological distress is somewhat more common in medical students than in the general population. Complications from stress include the development of mental disorders, drug abuse, anxiety, depression, and suicidal tendencies. ${ }^{2}$ Rafidah et $\mathrm{al}^{3}$ found that some degree of stress can improve learning ability and learning outcomes, and that a high degree of stress
Correspondence: Ihab Shafek Atta Pathology Department, Faculty of Medicine, Al-Azhar University, Assuit, Egypt Tel +966506651017

Email Ihab.bassyouny@azhar.edu.eg

Abdullah Almilaibary

Family and Community Medicine Department, Faculty of Medicine, Albaha University, Albaha, Al-Aqiq, Saudi Arabia Tel +9665545 I 3138

Email Aalmilaibary@bu.edu.sa 
can lead to the development of mental and physical health problems as well as reduced student self-esteem. ${ }^{4}$ ElMonshed et $\mathrm{al}^{5}$ reported that $40 \%$ and $74 \%$ of undergraduate students during the COVID-19 pandemic had stress and depression that required extensive work to eliminate and improve student academic performance.

In the evaluation of any integrated medical program, it is crucial that the medical educator, monitors, and academic counselors be aware of the prevalence, risk factors, and levels of stress among their students to prevent the impact of stress not only on health but also student performance, learning outcomes, and program evaluation.

An integrated medical curriculum promotes many types of teaching, learning, and assessment methods throughout the levels and phases of the curriculum. These create some degree of stress among medical students. The Albaha medical curriculum comprises 67 modules and courses that include three phases (preparatory, preclinical, and clinical) and 12 levels (two semesters by year). The preparatory phase consists of university and faculty required courses and is a prerequisite for the preclinical phase, which in turn is a prerequisite for the clinical phase. ${ }^{6,7}$

The 67 modules and courses are represented in a primarily horizontal way. Horizontal modules are performed in sequential order with no interval period of rest between these modules. This reflects some sort of stress among the students that may interfere with the acquisition of knowledge, especially within cognitive and skills domain. The process enhances student performance and learning outcome achievement.

Student-centered activities require pre-activity preparation, as they promote the acquisition of interpersonal communication, presentation, and values skills. ${ }^{8,9}$ The assessments and evaluation for each module range from 3-5 assessment models: quizzes, objective structured practical/clinical examination (OSPE/OSCE), continuous activity assessments, and a final exam. All these activities create stress in medical students, especially those involved with an integrated curriculum.

Like any integrated medical curriculum, the Albaha curriculum has areas of similarities but is unique in that integration is not restricted to only the basic or preclinical years, but also extended to involve the clinical years through multidisciplinary, intradisciplinary and interdisciplinary forms that are considered a high level of integration. This is supported by previous studies. ${ }^{10,11}$ It also includes specific modules that are community and research oriented.
Several curricular changes were made to adopt the learning environment to the COVID-19 pandemic. These changes include the introduction of blended learning, long day schedules, modified teaching strategies to become more student-centered, modifications to bedside teaching to use simulation instead of real patients in clinical situations, and modification of assessment methods. All these modifications may result in some degree of stress among the students.

In general, many prior studies have measured the degree of stress among medical students, ${ }^{12-14}$ and some of these studies evaluated the effects of stress on student performance. ${ }^{15-17}$ However, the degree of student stress during COVID-19 has not been fully studied. The degree of stress was assessed in some medical schools preCOVID, and the highest stress proportion was found in Thai medical schools $(61.4 \%),{ }^{18}$ followed by Malaysia $41.9 \%{ }^{19}$ and some British universities $(31.2 \%) .{ }^{14}$ Depression was observed in $12.9 \%$ of Swedish students, with a suicidal tendency in $2.7 \%{ }^{16}$

Psychological depression and stress among medical students lie along a wide spectrum as described by the Kessler instrument, which divides stress into no stress, mild, moderate, and severe levels. ${ }^{20}$ The selection of the Kessler instrument for use in the present study was due primarily because it is a scaler measure that gives answers with a spectrum of potential responses that tend to be steadier over time and with higher planes of reliability, as noted with the dichotomous evaluation that have a narrow spectrum of response in the form of the presence or absence of symptoms. Scalar scores are generally not affected by relatively minor changes in psychological behavior. ${ }^{21,22}$

The purpose of the present study was to detect and estimate the degree and prevalence of student stress among Albaha medical students via a mixed quantitative and qualitative approach. It also sought to identify risk factors for stress and to correlate the degree of stress with performance and curriculum phase.

\section{Methods}

This study was carried out following ethical approval from the ethical committee of Albaha Faculty of Medicine under Com/2021/32. Written informed consent was obtained from all participants.

A cross-sectional, quantitative, and qualitative study was performed on 337 medical students (203 males and 134 females). Students represented the three phases of the Bachelor of Medicine and Bachelor of Surgery 
(MBBS) program. Prevalence and degree of stress were measured using a valid and well-structured questionnaire. The questionnaire was divided into three main parts: the first part was the 10 -question Kessler instrument; ${ }^{20}$ the second part is made up of 10 specific questions that investigate the cause of the stress; and the third part was a qualitative component to report additional information about the sources of stress. The Kessler instrument, initially applied by Kessler, ${ }^{20}$ is widely used in surveys, especially those performed by the World Health Organization, to investigate stress and its impact on clinical outcomes. It has also been shown to be a good instrument for the estimation of psychometric elements, with a 0.89 Cronbach alpha and a confidence interval of $0.89 .^{23-26}$ The importance of the confidence interval is to ensure the reliability of the Kessler instrument and to support the reliability of the present study in comparison with previous works.

The Kessler instrument divides stress into none, mild, moderate, and severe categories. The five potential responses to each question range from "none of the time" to "all the time" and were scored from 1 to 5, respectively. The other 10 questions were organized based on all curricular components, including contents, teaching strategies, policy of assessment, learning resources/facilities, student-centered activities, and extracurricular activities. The aim of the 10 questions was to aid in the identification of sources of stress and are adjusted methodically by educational professionals to improve the validity of the questionnaire. These 10 questions have Likert scale-like responses and were scored from 1 to 5, ranging from strongly agree to strongly disagree. The third part is a qualitative section that allows the students to write about their academic performance and achievement, history of medical illness and drug intake, and sources of stress.

Two pilot studies were performed on males and females. Each group consisted of 35 students with a onemonth interval period between the two studies. The results obtained from the male and female groups were similar, affirming that the questionnaire was coherent, valid, and reliable. According to the reliability and validity obtained from the pilot studies, both the male and female groups were entered into the current study.

For the Kessler instrument questionnaire, scores were interpreted as follows: a score of less than 20 was considered negative for stress at any level (alert), a score of 20-24 was considered mild stress (resistance phase), 25-29 indicated moderate stress (near exhaustion), and 30-50 denoted severe stress (exhaustion). ${ }^{27-31}$ Each of the 10questions were analyzed separately. For both questionnaires, descriptive studies in the form of mean, standard deviation, and confidence interval (CI) were used in addition to the analysis of variance (ANOVA) and Student's $t$-tests to compare the frequencies and means of continuous variables in relation to levels of stress. The $\mathrm{P}$-value of $<0.05$ was considered significant.

\section{Results}

\section{Interpretation of Data}

The distribution of the current study was as follows: Phase I; 87 (25.8\%), Phase II; 123 (36.5\%), and phase III: 127 (37.9\%). Stress was measured in 288 students $(85.5 \%)$ and was distributed as follows: mild $81(24 \%)$, moderate 101 (30\%), severe $106(31.5 \%)$, and no stress in 49 out of 337 $(14.5 \%)$ ( $\mathrm{p}$-value $<0.00001$ using the ANOVA test). The overall mean of the Kessler instrument was 27.1, with a 95\% confidence interval of (27.1); 26.1-28.2 and a coefficient of variation of $34.46 \%$. The mean Kessler score for each group was $13.87,21.83,26.66$, and 40.61 for no stress and mild, moderate, and severe stress, respectively.

Due to the unequal representation of male and female students in the current study, the following stress results (number and percentage) were related to the total number of each male and female group. Furthermore, the stress percentage calculation was related to the number of students in each section. Regarding the phase of the curriculum, the percentage applied to each raw value was related to the number of students in each phase for either the male or female section. Student grade was related to the total number of studies (337) due to the unification of the assessment methods between the male and female sections.

The detailed description of the results revealed that the prevalence of stress among the integrated MBBS program of Albaha University was high, accounting for $85.5 \%$ with a slight male predominance $(86.6 \%)$ compared with females (83.6). Analysis of these results against sex and program phase revealed that the prevalence of stress was highest during phase I $(85.75 \%)$, followed by phase II (85.45\%) and phase III (84.1\%) (Table 1).

Regarding sex, the highest stress ratio was seen among the male students of phase I $(88.25 \%)$, followed by male students of phase III (87.7\%), female students of phase II 
Table I Sex, MBBS Phase, and Grade Characteristics

\begin{tabular}{|c|c|c|c|c|c|c|c|c|}
\hline \multicolumn{2}{|c|}{ Variable } & \multicolumn{4}{|c|}{ Sex; No. and Percentage } & \multirow[t]{3}{*}{ Total } & \multirow{3}{*}{$\begin{array}{c}\text { P-value (Student } \\
t \text { Test) }\end{array}$} & \multirow{3}{*}{$\begin{array}{c}t \text {-value (Student } \\
t \text { Test) }\end{array}$} \\
\hline \multirow{3}{*}{\multicolumn{2}{|c|}{ Sex }} & \multicolumn{2}{|c|}{ Male } & \multicolumn{2}{|c|}{ Female } & & & \\
\hline & & No & $\% *$ & No & $\% *$ & & & \\
\hline & & 203 & 60.2 & 134 & 39.7 & 337 & & \\
\hline \multirow[t]{3}{*}{ Phase } & 1 & 51 & 25.1 & 36 & 26.9 & 87 & \multirow[t]{3}{*}{0.497} & \multirow[t]{3}{*}{-0.0059} \\
\hline & II & 71 & 34.9 & 52 & 38.8 & 123 & & \\
\hline & III & 81 & 39.9 & 46 & 34.3 & 127 & & \\
\hline \multirow[t]{3}{*}{ Grade } & High & 49 & 24.1 & 43 & 36.6 & 92 & \multirow[t]{3}{*}{0.402} & \multirow[t]{3}{*}{-0.264} \\
\hline & Moderate & 88 & 43.3 & 44 & 32.8 & 132 & & \\
\hline & Low & 66 & 32.5 & 47 & 35 & 113 & & \\
\hline
\end{tabular}

Note: *Percentage of number of students to its actual number in both the male and female sections.

(86.5\%), male students of phase II (84.5\%), female students of phase I (83.3\%), and female students of phase III (80.4\%). Furthermore, the prevalence of stress was highest during phase I (86.2\%), followed by phase II (85.4\%) and phase III (85.1\%) (Table 2). The degree of moderate and severe stress was the highest during phase III (63.8\%), followed by phase I (62\%) and phase II (58.5\%) with a highly significant p-value $(<.00001)$ (Tables 2 and 3) (Figure 1).

In general, the total percentage of moderate and severe stress was higher in the male section (68.6\%) compared with the female section (57.4\%). The highest ratio was seen among the male students of phase III (66.6\%) and phase I (64.7\%), followed by the male students of phase II (59.2), the female students of phase III (58.7), the female students of phase I (58.4\%), and the female students of phase II (57.8\%). A higher percentage of severe stress was seen in the male section than in the female section, as evident during phase II (33.8\%), phase I (33.3\%), and phase III (32\%) compared with $30.6 \%, 30.4 \%$ and $27 \%$, respectively ( $<<0.00001$ ) (Tables 2 and 3). All descriptive studies are listed in Table 4.

Low level of stress among students who achieved high grades ranged from $2.4 \%$ to $4.7 \%$. High levels of stress were observed among male students who attained moderate grades $(\mathrm{B}+, \mathrm{C})(10.4 \%)$, followed by male students who attained low grades $(\mathrm{D}+, \mathrm{D})(7.1 \%)$. No association between stress and academic grades was observed. Furthermore,

Table 2 Distribution of the Degree of Stress by Sex and Program Phase

\begin{tabular}{|c|c|c|c|c|c|c|c|c|c|c|c|}
\hline \multirow{5}{*}{$\begin{array}{l}\text { Phase of the } \\
\text { Program }\end{array}$} & \multirow[t]{3}{*}{ Sex } & \multirow[t]{2}{*}{ Total } & \multicolumn{8}{|c|}{ Stress: Degree, No., Percentage, Mean 士SD } & \multirow{2}{*}{$\begin{array}{c}\text { P value } \\
\text { (ANOVA) }\end{array}$} \\
\hline & & & No Stress & $\begin{array}{l}\text { Mean } \\
\pm S D\end{array}$ & Mild & $\begin{array}{l}\text { Mean } \\
\pm \text { SD }\end{array}$ & Moderate & $\begin{array}{l}\text { Mean } \\
\pm S D\end{array}$ & Severe & $\begin{array}{l}\text { Mean } \\
\pm S D\end{array}$ & \\
\hline & & 337 & $49(14.5)$ & $13.88 \pm$ & $81(24)$ & $21.83 \pm$ & $101(30)$ & $26.66 \pm$ & $106(31.5)$ & $40.61 \pm$ & 0.0001 \\
\hline & Male & $203(60.2)$ & $27 / 203(13.3)$ & $14.3 \pm 2.38$ & $47(23.1)$ & $21.84 \pm 1.25$ & $62(30.5)$ & $26.75 \pm 1.4$ & $67(33)$ & $40.42 \pm 5.78$ & 0.4922 \\
\hline & Female & $134(39.7)$ & $22 / 134(16.4)$ & $13.36 \pm 2.64$ & $36(26.8)$ & $21.82 \pm 1.14$ & $39(29.1)$ & $26.54 \pm 1.28$ & 39 (29.1) & $40.94 \pm 5.8$ & \\
\hline \multirow[t]{2}{*}{1} & Male & $51 / 203(25.1)$ & $6 / 51(11.8)$ & $14.6 \pm 3.14$ & $12(23.5)$ & $21.4 \pm 1.25$ & $16(31.4)$ & $26.75 \pm 1.29$ & $17(33.3)$ & $4 I \pm 5.3$ & \multirow[t]{2}{*}{0.4729} \\
\hline & Female & $36 / 134(26.8)$ & $6 / 36(16.7)$ & $12.5 \pm 2.14$ & $9(25)$ & $21.88 \pm 0.99$ & $10(27.8)$ & $26 \pm 1$ & II (30.6) & $40.9 \pm 5.36$ & \\
\hline \multirow[t]{2}{*}{ II } & Male & $7 \mid / 201$ (34.9) & II/7| (15.5) & $14.27 \pm 3.65$ & $18(25.4)$ & $21.66 \pm 1.41$ & $18(25.4)$ & $26.88 \pm 1.36$ & 24 (33.8) & $40.5 \pm 6.41$ & \multirow[t]{2}{*}{0.4989} \\
\hline & Female & $52 / 134(38.8)$ & $7 / 52(13.5)$ & $13.57 \pm 2.32$ & $15(28.9)$ & $22 \pm 1.26$ & $16(30.8)$ & $26.37 \pm 1.16$ & $14(27)$ & $41.28 \pm 5.31$ & \\
\hline \multirow[t]{2}{*}{ III } & Male & $81 / 203$ (39.9) & $10 / 81(12.3)$ & $14.1 \pm 2.16$ & $17(2 \mathrm{I})$ & $22.05 \pm 1.05$ & $28(34.6)$ & $26.67 \pm 1.44$ & $26(32)$ & $40.42 \pm 4.85$ & \multirow[t]{2}{*}{0.1756} \\
\hline & Female & $46 / 134(34.3)$ & $9 / 46(19.6)$ & $14.11 \pm 2.6$ & $10(21.7)$ & $22.3 \pm 0.9$ & $13(28.3)$ & $26.92 \pm 1.54$ & $14(30.4)$ & $39.28 \pm 6.88$ & \\
\hline
\end{tabular}


Table 3 Summary of the Prevalence of Stress During Each Phase of the Program

\begin{tabular}{|l|c|c|c|c|}
\hline Section/Phase & $\begin{array}{c}\text { Percentage of } \\
\text { Stress }\end{array}$ & $\begin{array}{c}\text { Moderate and Severe } \\
\text { Stress }\end{array}$ & $\begin{array}{c}\text { P-value (Student's } \\
\text { t-Test) }\end{array}$ & $\begin{array}{c}\text { t-value (Student's } \\
\text { t-Test) }\end{array}$ \\
\hline Male section & 86.6 & 68.6 & 0.349 \\
\hline Female section & 83.6 & 67.4 & 0.0000 I & \\
\hline Stress during Phase I & 86.2 & 58.5 & \\
\hline Stress during Phase II & 85.4 & 63.8 & \\
\hline Stress during Phase III & 85.1 & 64.7 & \\
\hline Male students in phase I & 88.2 & 66.6 & \\
\hline Male students in phase III & 87.7 & 57.8 & \\
\hline Female students in phase II & 86.5 & 59.2 & \\
\hline Male students in phase II & 84.5 & 58.4 & \\
\hline Female students in phase I & 83.3 & 58.7 & \\
\hline Female students in phase III & 80.4 & & \\
\hline
\end{tabular}

there was no association between the grades of male and female students with the degree of stress (Table 5).

Analysis of the qualitative part of the study revealed that $85 \%$ of student stress was obtained from many evaluations of running modules, in addition to the evaluation of longitudinal modules which are inserted within these horizontal modules. Furthermore, $75 \%$ of students reported that many modules and their sequence without interval periods of rest were the cause of stress. Approximately $34-48 \%$ of students reported that studentcentered activities and their preparation were the main causes of stress. Other reported factors were medical

\section{Total percentage of stress compared to moderate and severe degree}

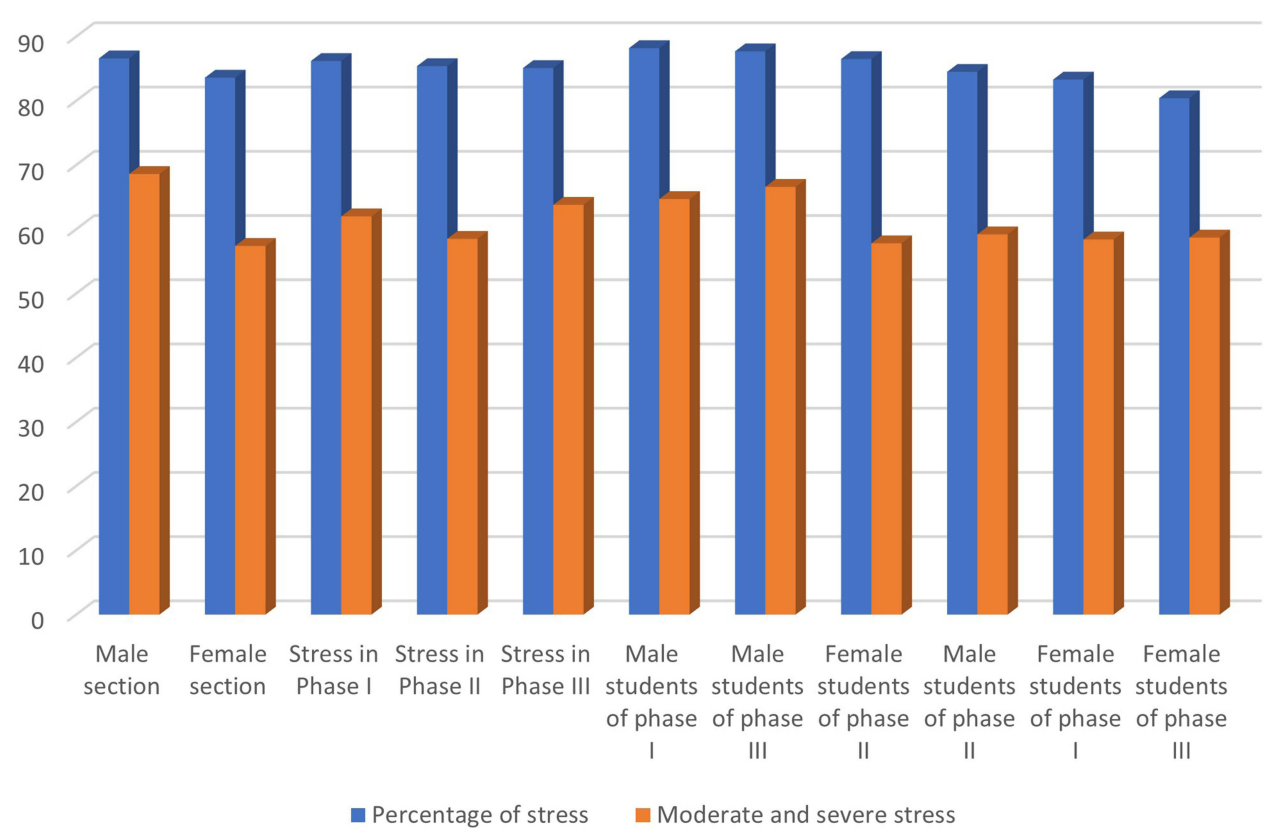

Figure I Overall vs moderate/severe in the current study by sex and phase. 
Table 4 Self-Reported Stress

\begin{tabular}{|c|c|c|c|c|c|c|c|c|}
\hline & \multicolumn{2}{|l|}{ No Stress } & \multicolumn{2}{|l|}{ Mild Stress } & \multicolumn{2}{|c|}{ Moderate Stress } & \multicolumn{2}{|c|}{ Severe Stress } \\
\hline & Male & Female & Male & Female & Male & Female & Male & Female \\
\hline Mean & 14.296 & 13.36 & 21.84 & 21.82 & 26.75 & 26.54 & 40.42 & 40.94 \\
\hline SD & 2.382 & 2.645 & 1.250 & 1.139 & 1.396 & 1.277 & 5.78 & 5.8 \\
\hline Median & 14 & 13 & 22 & 22 & 27 & 27 & 41 & $4 I$ \\
\hline Mode & 15 & 14 & 22 & 21 & 25 & 25 & 45 & 46 \\
\hline $\begin{array}{l}\text { Co of } \\
\text { Variation }\end{array}$ & 16.67 & 19.8 & 5.73 & 5.22 & 5.22 & 4.81 & $|4.3|$ & 14.19 \\
\hline $\begin{array}{l}\text { Confidence } \\
\text { interval }\end{array}$ & $\begin{array}{l}95 \% \\
\text { Confidence } \\
\text { Interval: } 14.3 \\
\pm 0.898 \text { (13.4 } \\
\text { to 15.2) }\end{array}$ & $\begin{array}{l}95 \% \\
\text { Confidence } \\
\text { Interval: } 13.4 \\
\pm \text { I.II (12.3 } \\
\text { to 14.5) }\end{array}$ & $\begin{array}{l}95 \% \\
\text { Confidence } \\
\text { Interval: } 21.8 \\
\pm 0.325(21.5 \\
\text { to } 22.1)\end{array}$ & $\begin{array}{l}95 \% \\
\text { Confidence } \\
\text { Interval: } 21.8 \\
\pm 0.476(21.3 \\
\text { to } 22.3)\end{array}$ & $\begin{array}{l}95 \% \\
\text { Confidence } \\
\text { Interval: } 26.7 \\
\pm 0.335 \text { (26.4 } \\
\text { to } 27)\end{array}$ & $\begin{array}{l}95 \% \\
\text { Confidence } \\
\text { Interval: } 26.5 \\
\pm 0.327(26.2 \\
\text { to } 26.8)\end{array}$ & $\begin{array}{l}95 \% \\
\text { Confidence } \\
\text { Interval: } 40.4 \\
\pm 1.57 \text { (38.8 } \\
\text { to } 42)\end{array}$ & $\begin{array}{l}5 \% \\
\text { Confidence } \\
\text { Interval: } 40.9 \\
\pm 2.05(38.9 \\
\text { to } 42.9)\end{array}$ \\
\hline
\end{tabular}

Table 5 Distribution of the Degree of Stress by Sex, Program Phase, and Academic Achievement

\begin{tabular}{|c|c|c|c|c|c|c|c|c|c|c|c|}
\hline \multirow[t]{2}{*}{ Grade } & \multirow{2}{*}{$\begin{array}{l}\text { Degree } \\
\text { of } \\
\text { Stress }\end{array}$} & \multicolumn{2}{|c|}{ Phase I } & \multicolumn{2}{|c|}{ Phase II } & \multicolumn{2}{|c|}{ Phase III } & \multirow[t]{2}{*}{ Total } & \multirow{2}{*}{$\begin{array}{l}\text { No. and } \\
\% \text { Male }\end{array}$} & \multirow{2}{*}{$\begin{array}{c}\text { No. and } \\
\% \text { of } \\
\text { Female }\end{array}$} & \multirow[t]{2}{*}{$P$ value } \\
\hline & & Male & Female & Male & Female & Male & Female & & & & \\
\hline \multirow{4}{*}{$\begin{array}{l}\text { High grade more than } \\
85 \%(A+, A, B+)\end{array}$} & No & 2 & 3 & 3 & 3 & 3 & 3 & I7 (5.04) * & $8(2.4)$ & $9(2.7)$ & \multirow[t]{4}{*}{0.230} \\
\hline & Mild & 3 & 4 & 4 & 4 & 4 & 2 & $21(6.2)$ & II (3.3) & $10(2.96)$ & \\
\hline & Moderate & 3 & 4 & 4 & 3 & 7 & 5 & $26(7.7)$ & $14(4.2)$ & $12(3.6)$ & \\
\hline & Severe & 4 & 4 & 7 & 5 & 5 & 3 & $28(8.3)$ & $16(4.7)$ & $12(3.6)$ & \\
\hline \multirow{4}{*}{$\begin{array}{l}\text { Moderate grade } \\
75-84 \%(B, C+)\end{array}$} & No & 2 & I & 4 & 2 & 3 & 3 & $15(4.5)$ & $9(2.7)$ & $6(1.8)$ & \multirow[t]{4}{*}{0.0509} \\
\hline & Mild & 6 & 3 & 8 & 6 & 6 & 5 & $34(10.08)$ & $20(5.9)$ & $14(4.2)$ & \\
\hline & Moderate & 8 & 2 & 7 & 8 & 9 & 4 & 38 (II.3) & $24(7.1)$ & $14(4.2)$ & \\
\hline & Severe & 9 & 3 & 13 & 3 & 13 & 4 & $45(13.4)$ & $35(10.4)$ & $10(2.96)$ & \\
\hline \multirow{4}{*}{$\begin{array}{l}\text { Low grade } 60-74 \% \\
(D+, D)\end{array}$} & No & 2 & 2 & 4 & 2 & 4 & 3 & $17(5.04)$ & $10(2.96)$ & $7(2.1)$ & \multirow[t]{4}{*}{0.116} \\
\hline & Mild & 3 & 2 & 6 & 5 & 7 & 3 & $26(7.7)$ & $16(4.7)$ & $10(2.96)$ & \\
\hline & Moderate & 5 & 4 & 7 & 5 & 12 & 4 & 37 (II) & $24(7.1)$ & $13(3.9)$ & \\
\hline & Severe & 4 & 4 & 4 & 6 & 8 & 7 & $33(9.8)$ & $16(4.7)$ & $17(5.04)$ & \\
\hline \multicolumn{2}{|l|}{ Total } & 51 & 36 & 71 & 52 & 81 & 46 & 337 & & & \\
\hline
\end{tabular}

Note: *This percentage is related to total number of study 337 due to unification of assessment methods between the male and female section.

illnesses and social factors, which represented $12 \%$ and $18 \%$, respectively (Table 6) (Figure 2).

\section{Discussion}

In the present study, the prevalence of stress among students taught with an integrated curriculum was high, accounting for $85.5 \%$ of students with a slight male predominance (86.6\%). This high percentage of stress may be due in part to curricular changes necessitated by the COVID-19 pandemic or other factors related to the integrated curriculum. The high student stress rate seen in the present work correlates with prior studies that have shown that medical 
Table 6 Sources of Stress as Reported by the Students in the Present Study

\begin{tabular}{|c|c|c|c|}
\hline Item & \multicolumn{2}{|c|}{$\begin{array}{c}\text { Some Important Reported Causes of Stress by the } \\
\text { Students }\end{array}$} & $\begin{array}{l}\text { No. and } \\
\text { Percentage }\end{array}$ \\
\hline Modules & \multicolumn{2}{|c|}{ Number. Sequences, no interval period of rest in-between } & $253(75 \%)$ \\
\hline Modules' contents & \multicolumn{2}{|c|}{ So condensed. Need more contact hours to learn } & $132(39.1 \%)$ \\
\hline \multirow[t]{2}{*}{$\begin{array}{l}\text { Student-centered activities and other small group } \\
\text { sessions }\end{array}$} & PBL, TBL, CBL & $\begin{array}{l}\text { Structure of tutorial contents Facilitator } \\
\text { role } \\
\text { Interpersonal communication } \\
\text { Preparation of my work } \\
\text { Presentation } \\
\text { Teamwork and group harmony } \\
\text { Timing } \\
\text { Personal student factors }\end{array}$ & $162(48 \%)$ \\
\hline & Seminar & $\begin{array}{l}\text { Language } \\
\text { Objectives } \\
\text { Preparation } \\
\text { Presentation } \\
\text { Resources and facilities } \\
\text { Inter-tutor bias marking }\end{array}$ & $117(34.7 \%)$ \\
\hline Assessments & \multicolumn{2}{|c|}{$\begin{array}{l}\text { Too many; at least } 4 \text { types of assessments per module in } \\
\text { addition to the assessments of longitudinal modules within the } \\
\text { horizontal modules } \\
\text { Usually done at the end of module, without enough time to } \\
\text { study } \\
\text { OSPE/OSCE environment; number and timing of stations }\end{array}$} & $\begin{array}{l}287(85.1 \%) \\
114(33.8 \%)\end{array}$ \\
\hline Medical illness & \multicolumn{2}{|c|}{ Acute and chronic medical illness } & $12(3.5 \%)$ \\
\hline Social factors & \multicolumn{2}{|c|}{ Residence, distance from family (Alienation), financial support } & $18(5.3 \%)$ \\
\hline
\end{tabular}

students experience a high level of stress during their undergraduate courses. ${ }^{32-36}$ The findings agree with the results of four studies from Arab countries such as Egypt and Saudi Arabia that reported a high level of depression and anxiety among medical students. ${ }^{37-40}$ It further agrees with Yang et $\mathrm{al}^{41}$ who found that changes due to COVID-19 in the form of an increased academic workload and fear of contagion resulted in increased student stress.

The findings of this work also agree with the study by Babicka-Wirkus et al $^{42}$ who reported an increased prevalence of stress during the COVID-19 pandemic and stated that younger students who are in the early stages of their academic career were less able to cope due to their short life experience. Furthermore, our results are in agreement with a prior study that showed that the COVID-19 pandemic has had a negative effect on higher education through higher levels of stress among students. ${ }^{43}$

Regarding sex differentiation and stress, we found a slight male predominance with an insignificant difference. This coincides with prior studies that found that sex gaps in stress levels are rare and insignificant. ${ }^{3,17,31}$ The slight male predominance seen in the present work coincides with the study by Abdel Rahman et $\mathrm{al}^{44}$ who found that men had higher levels of stress than women. The authors felt that this was because male students were careful to achieve high scores and end the program on time to enter the postgraduate phase and begin their careers. In contrast, other studies found a higher level of stress in female students. ${ }^{39,45}$ This sex debate may be due to differences in educational and social context in addition to the presence of subjectivity in the evaluation of the degree of stress by participants.

The prevalence of stress in the present work was highest during phase I $(85.75 \%)$, followed by phase II $(85.45 \%)$ and phase III $(84.1 \%)$. This high frequency of stress among students in phase I may be due to their change into university life. This transition phase requires students to acclimate to multiple new life changes. This 


\section{REPORTED CAUSES AND PERCENTAGE OF STRESS}

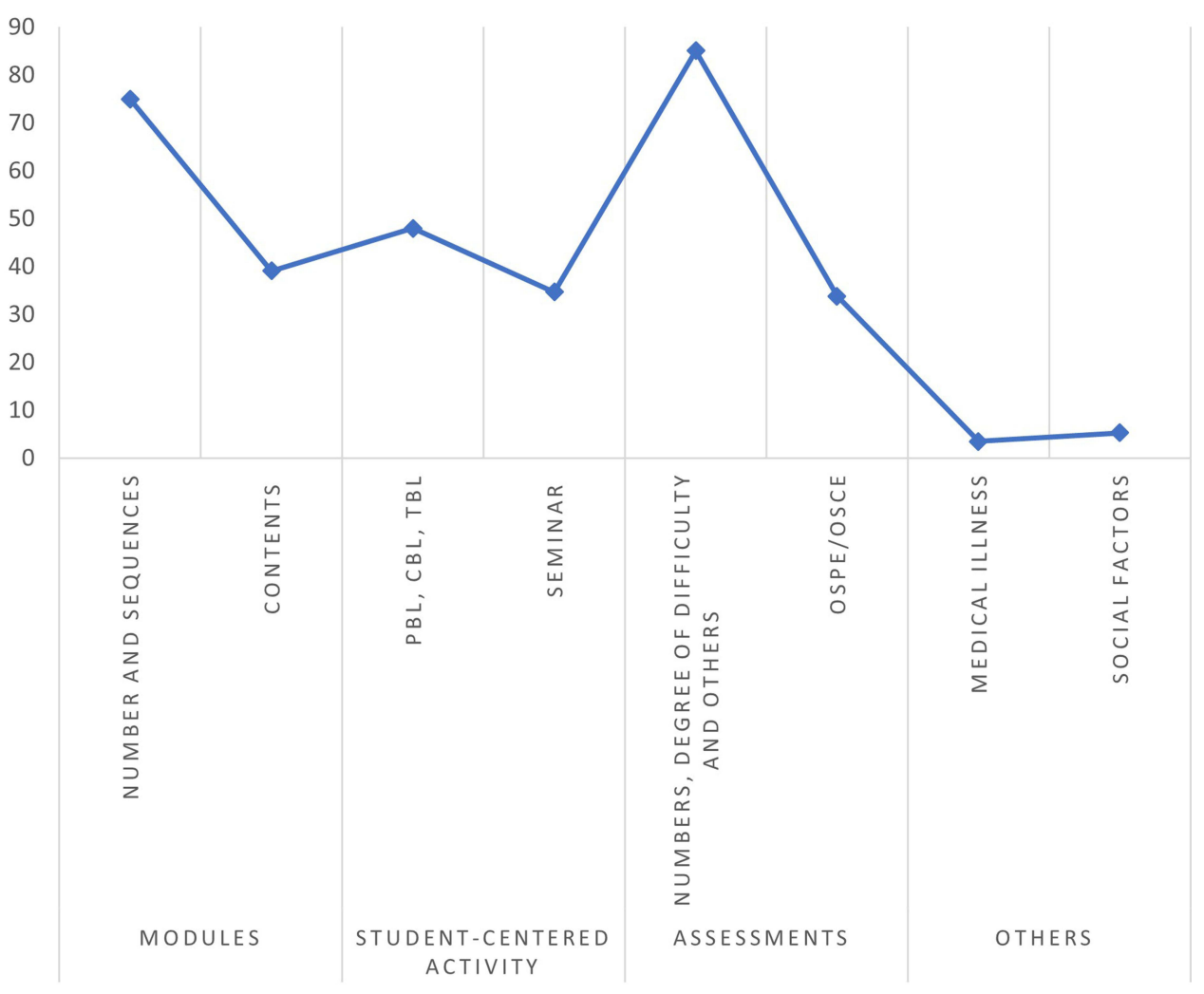

Figure 2 Student-reported causes of stress.

finding coincides with the study by Abdulghani et al ${ }^{40}$ who reported that stress was inversely proportional to academic year. In contrast, this finding contradicts with that of another study in which level of stress progressively increased during the program, reaching its highest level at the end of the clinical year. ${ }^{3}$ Imperative causes of stress among phase I students may be the large amounts of academic content, competition, time limit, fear of low achievement and failure, and social factors, all of which can cause psychological problems such as depression and anxiety. $^{46}$

The highest wave of stress among males was seen during the first year, followed by the third phase (clinical phase), with a slight decrease during Phase II. Among females, the biggest wave of stress was seen during Phase II, followed by phase I and Phase III. The high level of stress in men during phase I (first year) agrees with many prior studies such as the one by Stewart et $\mathrm{al}^{47}$ who reported a high prevalence of stress during the first year of the medical curriculum and recommended identifying vulnerable students early and provide them with academic and additional support to prevent stress.

Stress that appeared during the first year can continue throughout the study period and extend to internship and residency, thereby affecting the practical life of the physician. ${ }^{48}$ Furthermore, the degree of stress can reach burnout levels. $^{49}$ The high percentage of stress in our results coincides with the study by Botelho et al, ${ }^{23}$ who identified levels of stress in $71 \%$ of students taught with an integrated curriculum compared with $64 \%$ taught with a traditional curriculum. However, in contrast with our results the authors found a $72 \%$ female predominance of stress compared with $55 \%$ among males compared with $83.6 \%$ and $83.6 \%$, respectively.

The present study found no association between stress and academic grades. Furthermore, there was no association between the grades of male or female students and stress. This agrees with the study by Abdulghani et $\mathrm{al}^{40}$ who found no association between academic level and the presence or absence of stress. In the present study, students 
reported that assessments, number of modules, sequences, content, and student-centered activities including PBL, CBL, and TBL were the main causes of stress in addition to the stress caused by repeated assessments. This agrees with previous studies that have shown that studentcentered activities that include self-directed learning create a degree of stress among students, especially those of the integrated curriculum. ${ }^{50,51}$ This agrees with the results of Tarnowski et $\mathrm{al}^{52}$ and Costa et $\mathrm{al}^{53}$ who found that a heavy educational content and heavy workload intermingled with high educational needs, short leisure time, and limited contact with family and friends are factors that decrease quality of life and help develop student stress and burnout. Furthermore, these observations are also in agreement with Chhabra et $\mathrm{al}^{54}$ and Enns et $\mathrm{al}^{55}$ - who found that the educational climate and environment are crucial factors that influence the quality of life of medical studentsand Joseph et $\mathrm{al}^{56}$ on academic stress among medical students. Ramli et $\mathrm{al}^{57}$ found that academic stress was most frequent mental state that medical students experienced over their training period. Drolet and Rodgers ${ }^{58}$ explained that stress may be due to increasing course requirements. Kumaraswamy ${ }^{59}$ discussed stress in medical students and identified several factors that may lead to the development of stress, which include excessive assignments, multiple assessment, peer competition, and challenges associated with time management. Medical students are in contract with many stressors in the medical environment: strong academic requirements and assignments, challenging curricular characteristics and learning environments, personal life experiences, and psychological pressures that are hard to cope with. ${ }^{60,61}$

\section{Limitation of the Study}

This study was a cross-sectional analysis of a questionnaire that was completed by the students. This can lead to bias in the evaluation of the student's emotional reaction. Some students may overestimate their responses, some may insist on giving negative feedback on the curriculum, and others may be affected by their performance or social factors. Furthermore, student responses may be affected by changes in the learning environment due to the COVID-19 pandemic, which makes the environment more stressful. Longitudinal cohort studies must be performed that start with the firstlevel student and follow them to the end of their program to determine the actual percentage of stress at all levels and phases of the curriculum, especially after the end of the COVID-19 pandemic.

\section{Conclusion}

The study found a high level of stress throughout all phases of and integrated curriculum that was somewhat elevated during the first phase and decreased thereafter. The level of stress during all phases was similar, likely due to changes in the learning environment and curricular changes throughout all three phases that occurred during the COVID-19 pandemic. It is therefore not surprising to report this high stress level in the current study. No significances are noted between stress with either academic grade or phase of the curriculum. Some potential causes of stress as reported by the students include multiple assessments, the number of modules and their sequences, and the extensive homework from student-centered activities. The curriculum committee must revise the content, teaching strategies, and mode of assessments, and accordingly a minor or major modification should be done not only as a process of curricular reform but also to lessen the degree of stress among the students. These results suggest that teachers should observe and detect any signs of stress in their students. Activating student mentorship, including academic, psychic, and social counseling will help predict and manage stress among students and improve their achievements. We consider the detection of stress among students to be an important issue for program monitoring and development.

\section{Acknowledgment}

We would like to thank the students who participated in conducting the survey, as well as the faculty members for their support and assistance in motivating the students to participate actively.

\section{Funding}

No funding was received.

\section{Disclosure}

Ihab Shafek Atta is considered as first author. No conflict of interest to declare.

\section{References}

1. Dyrbye LN, Thomas MR, Huntington JL, et al. Personal life events and medical student burnout: a multicenter study. Acad Med. 2006;81 (4):374-384. doi:10.1097/00001888-200604000-00010 
2. Nandi M, Hazra A, Sarkar S, Mondal R, Ghosal MK. Stress, and its risk factors in medical students: an observational study from a medical college in India. Indian J Med Sci. 2012;66(1-2):1-12. doi:10.4103/0019-5359.110850

3. Rafidah K, Azizah A, Norzaid MD, Chong SC, Salwani MI, Noraini I. The impact of perceived stress and stress factors on academic performance of pre-diploma science students: a Malaysian study. Int J Sci Educ. 2009;2:13-26.

4. Niemi PM, Vainiomaki PT. Medical students' distress-quality, continuity, and gender differences during a six year medical programme. Med Teach. 2006;28:136-141. doi:10.1080/01421590600607088

5. El-Monshed AH, El-Adl AA, Ali AS, Loutfy A. University students under lockdown, the psychosocial effects and coping strategies during COVID-19 pandemic: a cross sectional study in Egypt. $J$ Am Coll Health. 2021;2:1-12. doi:10.1080/07448481.2021.1891086

6. Atta IS, AlQahtani FN. Integrated pathology and radiology learning for a musculoskeletal system module: an example of an interdisciplinary integrated form. Adv Med Educ Pract. 2018;9:527-533. doi:10.2147/AMEP.S167692

7. Atta IS, AlQahtani FN. How to adjust the strategy of radiopathologic teaching to achieve the learning outcomes? Int J Med Sci Public Health. 2018;7(2):86-91. doi:10.5455/ijmsph.2018.1130015122017

8. Atta IS, AlQahtani FN. Matching medical student achievement to learning objectives and outcomes: a paradigm shift for an implemented teaching module. Adv Med Educ Pract. 2018;9:227-233. doi:10.2147/AMEP.S158784

9. Atta IS, Alqahtani FN. Hybrid PBL radiology module in an integrated medical curriculum Al-Baha faculty of medicine experience. $J$ Contemp Med Edu. 2015;3(1):46-55. doi:10.5455/jcme.201 50525033016.

10. Atta IS, Alzahrani RA. Perception of pathology of otolaryngologyrelated subjects: students' perspective in an innovative multidisciplinary classroom. Adv Med Educ Pract. 2020;11:359-367. doi:10.2147/AMEP.S256693

11. Salha A, Saberi-Movahed AS, Syed Waqar. Medical student perspectives on integrated teaching within medical school. Adv Med Educ Pract. 2018;9:753-756

12. Bamuhair SS, Al Farhan AI, Althubaiti A, Agha S, Rahman S, Ibrahim NO. Sources of stress and coping strategies among undergraduate medical students enrolled in a problem-based learning curriculum. J Biomed Educ. 2015;1-8. doi:10.1155/2015/575139

13. Atta IS, El-Hag MA, Ihab Shafek S, Al-Ghamdi HS, Alghamdi TH. Drawbacks in the implementation of an integrated medical curriculum at medical schools and their potential solutions. Educ Med J. 2020;12(1):29-42. doi:10.21315/eimj2020.12.1.4

14. Ross S, Cleland J, Macleod MJ. Stress, debt and undergraduate medical student performance. Med Educ. 2006;40(6):584-589. doi:10.1111/j.1365-2929.2006.02448.x

15. Roberts J. Junior doctors' years: training not education. $B M J$. 1991;302:225-228. doi:10.1136/bmj.302.6770.225

16. Firth-Cozen J. Emotional distress in junior hospital doctors. $B M J$. 1987;295:533-536. doi:10.1136/bmj.295.6597.533

17. Firth J. Levels and sources in medical students. BMJ. 1986;292:1177-1180. doi:10.1136/bmj.292.6529.1177

18. Saipanish R. Stress among medical students in a Thai medical school. Med Teach. 2003;25:502-506. doi:10.1080/0142159031000136716

19. Sherina MS, Rampal L, Kaneson N. Psychological stress among undergraduate medical students. Med JMalaysia. 2004;59:207-211.

20. Kessler RC, Andrews G, Colpe LJ, et al. Short screening scales to monitor population prevalence and trends in non-specific psychological distress. Psychol Med. 2002;32:959-976. doi:10.1017/ S0033291702006074

21. Watson D. Rethinking the mood and anxiety disorders: a quantitative hierarchical model for DSM-V. J Abnorm Psychol. 2005;114 (2):522-536. doi:10.1037/0021-843X.114.4.522
22. Mitchell CM, Beals J. The utility of the Kessler screening scale for psychological distress (K6) in two American Indian communities. Psychol Assess. 2011;23(3):752-761. doi:10.1037/a0023288

23. Botelho F, Bergamo I, Oliveira M, et al. Stress level assessment of medical school program, and correlations between learning styles and teaching methodologies. AMEE MedEdPublish. 2017;6:22. doi:10.15694/mep.2017.000022

24. Cairney J, Veldhuizen S, Wade TJ, Kurdyak P, Streiner DL. Evaluation of 2 measures of psychological distress as screeners for depression in the general population. Can $J$ Psychiatry. 2007;52:111-120. doi:10.1177/070674370705200209

25. Brooks RT, Beard J, Steel Z. Factor structure and interpretation of the K10. Psychol Assess. 2006;18:62-70.

26. Forero R, Young L, Hillman KM, Bauman AE, Leraci S. Prevalence of psychological stress assessed in emergency departments. Emerg Med J. 2006;23:489. doi:10.1136/emj.2005.029090

27. Dahlin M, Joneborg N, Runeson B. Stress and depression among medical students: a cross-sectional study. Med Educ. 2005;39:594-604. doi:10.1111/j.1365-2929.2005.02176.x

28. Aktekin M, Karaman T, Senol YY, Erdem S, Erengin H, Akaydin M. Anxiety, depression, and stressful life events among medical students: a prospective study in Antalya, Turkey. Med Educ. 2001;35:12-17. doi:10.1046/j.1365-2923.2001.00726.x

29. Colby L, Mareka M, Pillay S, et al. The association between the levels of burnout and quality of life among fourth-year medical students at the University of the Free State. S Afr J Psychiat. 2018;24:a1101. doi:10.4102/sajpsychiatry.v24i0.1101

30. Botelho F, Bergamo I, Oliveira M, et al. Stress level assessment of medical school program, and correlations between learning styles and teaching methodologies. AMEE MedEdPublish. 2017;6(1):22. doi:10.15694/mep.2017.000022

31. Brooks RT, Beard J, Steel Z. Factor structure and interpretation of the K10. Psychol Assess. 2006;18:62-70. doi:10.1037/1040-3590.18.1.62

32. Kilkkinen A, Kao-Philpot A, O'Neil A, et al. Prevalence of psychological distress, anxiety and depression in rural communities in Australia. Aust J Rural Health. 2007;15:114-119. doi:10.1111/ j.1440-1584.2007.00863.x

33. Rosal MC, Ockene IS, Ockene JK, Barrett SV, Ma Y, Hebert JR. A longitudinal study of students' depression at one medical college. Acad Med. 1997;72:542-546. doi:10.1097/00001888-19970600000022

34. Stewart SM, Lam TH, Betson CL, Wong CM, Wong AM. A prospective analysis of stress and academic performance in the first two years of medical school. Med Educ. 1999;33:243-250. doi:10.1046/j.1365-2923.1999.00294.x

35. Singh G, Hankins M, Weinman JA. Does medical school cause health anxiety and worry in medical students? Med Educ. 2004;38:479-481. doi:10.1046/j.1365-2929.2004.01813.x

36. Wilkinsos TJ, Gill DJ, Fitzjohn J, Palmer CL, Mulder RT. The impact on students of adverse experiences during medical school. Med Teach. 2006;28:129-135. doi:10.1080/01421590600607195

37. Styles WM. Stress in undergraduate medical education: "the mask of relaxed brilliance". Br J Gen Pract. 1993;43:46-47.

38. El-Gilany AH, Amr M, Hammad S. Perceived stress among male medical students in Egypt and Saudi Arabia: effect of sociodemographic factors. Ann Saudi Med. 2008;28:442-448. doi:10.5144/ 0256-4947.2008.442

39. Amr M, El-Gilany A, El-Sayed M, El-Sheshtawy E. Study of stress among medical students at Mansoura University. Banha Med J. 2007;37:25-31.

40. Abdulghani HM, AlKanhal AA, Mahmoud ES, Ponnamperuma GG, Alfaris EA. Stress and its effects on medical students: a cross-sectional study at a college of medicine in Saudi Arabia. $J$ Health Popul Nutr. 2011;29(5):516-522. doi:10.3329/jhpn. v29i5.8906 
41. Yang C, Chen A, Chen Y. College students' stress and health in the COVID-19 pandemic: the role of academic workload, separation from school, and fears of contagion. PLoS One. 2021;16(2): e0246676. doi:10.1371/journal.pone.0246676

42. Babicka-Wirkus A, Wirkus L, Stasiak K, Kozłowski P. University students' strategies of coping with stress during the coronavirus pandemic: data from Poland. PLoS One. 2021;16(7):e0255041. doi:10.1371/journal.pone.0255041

43. Son C, Hegde S, Smith A, Wang X, Sasangohar F. Effects of COVID-19 on college students' mental health in the United States: interview survey study. J Med Internet Res. 2020;22(9):e21279. doi:10.2196/21279

44. Abdel Rahman AG, Al Hashim BN, Al Hiji NK, Al-Abbad Z. Stress among medical Saudi students at college of medicine, King Faisal University. J Prev Med Hyg. 2013;54(4):195-199.

45. Saeed AA, Bahnassy AA, Al-Hamdan NA, Almudhaibery FS, Alyahya AZ. Perceived stress and associated factors among medical students. J Family Community Med. 2016;23(3):166-171. doi:10.4103/2230-8229.189132

46. Aguiar SM, Vieira APGF, Vieira KMF, Aguiar SM, Nobrega JO. Prevalencia de sintomas de estresse nos estudantes de medicina. J Bras Psiquiatr. 2009;58:34-38. doi:10.1590/S0047-20852009000 100005

47. Stewart SM, Betson C, Lam TH, Marshall IB, Lee PW, Wong CM. Predicting stress in first year medical students: a longitudinal study. Med Educ. 1997;31(3):163-168. doi:10.1111/j.1365-2923.1997.tb02560.x

48. Tyssen R, Vaglum P, Gronvold NT, Ekeberg O. The relative importance of individual and organizational factors for the prevention of job stress during internship: a nationwide and prospective study. Med Teach. 2005;27:27-31. doi:10.1080/01421590500314561

49. Willcock S, Daly MG, Tennant CC, Allard BJ. Burnout and psychiatric morbidity in new medical graduates. Med J Aust. 2004;181:357-360. doi:10.5694/j.1326-5377.2004.tb06325.x

50. Atta IS, AlQahtani FN, Alghamdi TA, Mankrawi SA, Alamri AM. Can pathology- teaching' strategy be affected by the students' learning style and to what extent the students' performance be affected? Glo Adv Res J Med Med Sci. 2017;6(11):296-301.

51. Atta IS, Alghamdi AH. The efficacy of self-directed learning versus problem-based learning for teaching and learning ophthalmology: a comparative study. Adv Med Educ Pract. 2018;9:623-630. doi:10.2147/AMEP.S171328
52. Tarnowski M, Carlotto MS. Burnout syndrome in students of psychology. Temas em Psicologia. 2007;15(2):173-180.

53. Costa EF, Santos SA, Santos AT, Melo EV, Andrade TM. Burnout syndrome and associated factors among medical students: a cross-sectional study. Clinics. 2012;67(6):573-580. doi:10.6061/clinics/ 2012(06)05

54. Chhabra S, Misra A, Shah S, Kole T. Survey of student perception of medical education environment among emergency medicine residents of an academic medical centre in Northern India. Int $J$ Emerg Med. 2016;9(1):5. doi:10.1186/s12245-016-0098-3

55. Enns SC, Perotta B, Paro HB, et al. Medical students' perception of their educational environment and quality of life: is there a positive association? Acad Med. 2016;91(3):409-417. doi:10.1097/ ACM.0000000000000952

56. Joseph N, Nallapati A, Machado MX, Matele S, Muthusamy N, Aditi Sinha A. Assessment of academic stress and its coping mechanisms among medical undergraduate students in a large Midwestern university. Curr Psychol. 2021;40:2599-2609. doi:10.1007/s12144-020-00963-2

57. Ramli NHH, Alavi M, Mehrinezhad SA, Ahmadi A. Academic stress and self-regulation among university students in Malaysia: mediator role of mindfulness. Behav Sci. 2018;8:12-16. doi:10.3390/bs8010012

58. Drolet BC, Rodgers S. A comprehensive medical student wellness program-design and implementation at Vanderbilt School of Medicine. Acad Med. 2010;85:103-110. doi:10.1097/ ACM.0b013e3181c46963

59. Kumaraswamy N. Academic stress, anxiety, and depression among college students - a brief review. Int Rev Soc Sci Humanit. 2013;5:135-143.

60. Dyrbye LN, Thomas MR, Harper W, et al. The learning environment and medical student burnout: a multicentre study. Med Educ. 2009;43 (3):274-282. doi:10.1111/j.1365-2923.2008.03282.x

61. Santen SA, Holt DB, Kemp JD, Hemphill RR. Burnout in medical students: examining the prevalence and associated factors. South Med J. 2010;103(8):758. doi:10.1097/SMJ.0b013e3181e6d6d4
Advances in Medical Education and Practice

\section{Publish your work in this journal}

Advances in Medical Education and Practice is an international, peerreviewed, open access journal that aims to present and publish research on Medical Education covering medical, dental, nursing and allied health care professional education. The journal covers undergraduate education, postgraduate training and continuing medical education
Dovepress

including emerging trends and innovative models linking education, research, and health care services. The manuscript management system is completely online and includes a very quick and fair peer-review system. Visit http://www.dovepress.com/testimonials.php to read real quotes from published authors. 